PN N L-12061

Interim Report

\title{
ENERGY R\&D IN THE INDUSTRIALIZED WORLD: RETRENCHMENT AND REFOCUSING
}

JJ Dooley", PJ Runci", EEM Luiten ${ }^{+}$

"Pacific Northwest National Laboratory

${ }^{+}$Utrecht University, The Netherlands

December 1998

Prepared for

U.S. D epartment of Energy

under Contract DE-A C 06-76R LO 1830

Pacific N orthwest N ational Laboratory

$O$ perated for the U.S. D epartment of Energy

by Battelle M emorial Institute

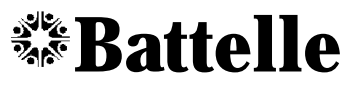


PNNL-12061

Interim Report

\title{
DISCLAIMER
}

This report was prepared as an account of work sponsored by an agency of the United States Government. Neither the United States Government nor any agency thereof, nor Battelle Memorial Institute, nor any of their employees, makes any warranty, express or implied, or assumes any legal liability or responsibility for the accuracy, completeness, or usefulness of any information, apparatus, product, or process disclosed, or represents that its use would not infringe privately owned rights. Reference herein to any specific commercial product, process, or service by trade name, trademark, manufacturer, or otherwise does not necessarily constitute or imply its endorsement, recommendation, or favoring by the United States Government or any agency thereof, or Battelle Memorial Institute. The views and opinions of authors expressed herein do not necessarily state or reflect those of the United States Government or any agency thereof.

\author{
PACIFIC NORTHWEST NATIONAL LABORATORY \\ operated by \\ BATTELLE MEMORIAL INSTITUTE \\ for the \\ UNITED STATESDEPARTMENT OF ENERGY \\ under Contract DE-A C06-76RLO 1830
}


PNNL-12061

Interim Report

\begin{abstract}
This report presents preliminary findings from an ongoing research project examining trends in energy $R \& D$ investments in selected industrialized countries (The United States, Japan, Germany, the N etherlands, and the European Union). Its underlying purpose is to assess the adequacy of current energy $R \& D$, in terms of investment levels and programmatic scope considering the likely energy technology demands associated with international efforts to address global climate change.

It finds that, while overall levels of public and private investment in all forms of R\&D have risen significantly across the countries studied, investments in energy $R \& D$ have declined in real terms. Causes of the observed decline might include the ongoing deregulation of the energy industries, the absence of acute energy crises, and shifts in domestic social and policy priorities in the post-Cold War period. In addition, it finds noteworthy shifts within industrialized countries' energy R\&D investment portfolios. In most countries, nuclear R\&D has declined (by more than $90 \%$ in key countries such as the U.S. and Germany) while the remaining $R \& D$ resources are shifting toward shorter-term projects, most notably in the energy efficiency area. Research on carbon sequestration, hydrogen production, and fuel cells is gaining in prominence public sector energy $R \& D$, often displacing traditional fossil energy $R \& D$ projects.

Future research associated with this project will include the preparation of reports on several additional industrialized countries, including the United Kingdom, France, Italy, Canada, and Switzerland. Collectively, the small set of countries addressed in this project account for over $95 \%$ of the world's energy $R \& D$.
\end{abstract}

KEY WORD S: Energy R\&D, Deregulation, Global Climate Change, Energy Technologies 


\section{Summary of Findings and Conclusions}

This report is an interim summary of crosscutting findings arising from an analysis of the R\&D efforts of four major industrialized nations (the United States, Japan, Germany and the Netherlands) and of the European Union. The second phase of this project will continue to refine these five case studies and will expand to include case studies of Canada, France, Italy, Switzerland, and the United Kingdom. This ongoing research effort seeks to assess the adequacy of the industrialized world's energy R\&D programs, particularly in the light of the significant energy technology challenges that global climate change could soon pose. Since the nine countries mentioned above collectively account for over $95 \%$ of the world's energy R\&D investments, their current commitments to energy R\&D will determine in large part the range of technology options at the world's disposal in upcoming decades.

We find:

- Overall national R\&D efforts (i.e., public and private sector research in all fields of inquiry) have grown strongly over the past decade. But the fraction of national R\&D activities sponsored by national governments has declined steadily. Moreover, publicly sponsored $\mathrm{R} \& \mathrm{D}$ is not keeping pace with economic growth over the past decade, i.e., public sector R\&D as a percent of gross domestic product is in decline. In many countries, the absolute level of public support for R\&D in the 1990s has exhibited relatively slow growth, compared either with recent private sector investments or the public investments of previous decades.

- Unlike overall national R\&D, national energy R\&D efforts have not experienced significant growth over the past decade. In the nations surveyed, the dominant trend has been toward significant reductions in publicly funded energy R\&D. Energy R\&D as a percent of total public sector R\&D and as a percent of gross domestic product has also been in decline in all of these nations. Where data are available, it is evident that private sector energy $\mathrm{R} \& \mathrm{D}$ investment is also in decline. The absence of a perceived energy crisis, the deregulation of the energy industries, and pressures to reduce governmental spending appear to be significant explanatory variables for this disinvestment in energy R\&D. These same drivers are likely to continue to depress energy R\&D investment levels for the foreseeable future.

- The performance of energy $R \& D$ is highly concentrated in a very small number of countries. The top 9 nations account for $95 \%$ of the industrialized world's publicly supported energy R\&D. The US and Japan, the countries with the largest public energy programs, both fund approximately the same level of energy R\&D, slightly more than $\$ 2$ billion in 1996 . No other country funds even half the level of these two nations. In fact, Japan's fission energy R\&D budget alone is larger than the sum of the Netherlands, EU, and German total energy R\&D budgets.

- The beginning of a potentially significant transition in fossil energy research programs is now discernible, wherein programs are seeking to develop zero carbon dioxide emitting fossil fuel technologies. Key technologies that are beginning to receive budget preference include methods to "decarbonize" fossil fuels, fuel cells, and methods to dispose of or sequester carbon dioxide wastes. The total amount of resources committed to these technology areas is currently small, however.

- The concept of "fossil fuels" is being expanded by research designed to assess the viability of developing methane hydrate and coal bed methane reservoirs. The emergence of these advanced fossil programs, in conjunction with programs to develop carbon sequestration 
technologies, signals the possible continued viability of potentially abundant and cheap fossil fuels for the next century, even in the face of greenhouse gas emissions restrictions. Of the countries surveyed, Japan is the largest supporter of these non-conventional fossil energy research efforts.

- Among the countries studied, renewable energy R\&D programs have become more concentrated in the area of solar photovoltaics. Perhaps surprisingly, renewable energy R\&D programs have had relatively stagnant budgets throughout the past decade even though the nations that fund this research have adopted energy policies advocating increased use of renewable energy as a means of reducing both carbon dioxide emissions, local air pollution, and dependence on foreign energy sources.

- Energy efficiency R\&D programs have experienced the most consistent budget growth of all technology areas. Industrial energy efficiency programs appear to be receiving preference for R\&D funds over buildings or transportation related energy efficiency programs. This preference for industrial energy efficiency $R \& D$ reflects both a desire to improve international economic competitiveness and environmental quality.

- The future of nuclear energy and related technologies is in a period of great uncertainty in many countries. Many nations are shifting an ever-larger share of their fission energy R\&D programs away from the development of new reactors and components to focus on research activities concerned with the nuclear fuel cycle, waste disposal, and reactor decommissioning. Major international fusion technology R\&D programs, particularly the International Thermonuclear Experimental Reactor (ITER), are also going through a period of turbulence, as sponsoring nations such as the U.S. reassess their commitments to this technology area.

We conclude:

- Budgetary pressures, energy deregulation, and the perceived lack of an "energy crisis" are likely to suppress government energy R\&D budgets for the foreseeable future. In the absence of major shifts in the world energy outlook, government energy R\&D investments appear unlikely to be restructured and expanded in a way that is optimal for developing the technologies needed in the middle to long term to avoid global climate change.

- The current turmoil in private sector energy R\&D programs brought about in large measure by the push to deregulate energy industries will continue to place downward pressure on private sector investments in longer term energy R\&D.

- Public energy R\&D is evolving in important ways from the perspective of climate change. Research programs aimed at the development of fuel cells, hydrogen infrastructure technologies, and carbon capture and disposal technologies represent a small but growing percentage of government energy R\&D investment.

- There is an increasing gap between governments' aspirations to curb carbon dioxide emissions, as expressed in policy statements and their funding commitments to energy R\&D. Many nations appear to have adopted a de facto policy of relying on the further deployment of existing energy efficiency technologies, fuel switching and emissions trading as the primary means of reducing carbon dioxide emissions. 


\section{Introduction: Energy R\&D in Decline}

For well over a decade, the world has enjoyed a period of cheap and abundant energy supplies. Since the oil shocks of the 1970s, a combination of factors, including technological advances, discoveries of new petroleum resources, improved energy productivity, and the creation of futures markets, has alleviated fears that the energy future would necessarily be characterized by scarcity and high prices. The 1990-91 Persian Gulf War, which caused only a brief price spike on international energy markets, ultimately bolstered optimism concerning the world's improved adeptness at managing energy crises.

Amid the general energy optimism that has persisted since the mid-1980s, government investments in energy research and development (R\&D) have declined in many advanced industrial countries. To a great extent, the reduction in government commitments to energy $R \& D$ reflects the perception that energy has become a matter of lesser urgency, relative to other social priorities.

At the same time, an ideological shift in the industrialized countries toward the deregulation of key industries, such as electric and gas utilities, has placed additional pressures on R\&D investments. With the introduction of competitive forces in the energy industries and the elimination of guaranteed returns, firms' (and in particular energy utilities') R\&D investments have grown smaller. Remaining R\&D resources gravitate more often to lower risk, marketoriented projects than to riskier projects with more distant payoffs. ${ }^{1}$

Yet, while public and private sector energy R\&D investments have declined, a major new energy challenge has appeared on the horizon that will demand significant and sustained commitments to the development of new energy technologies. The challenge of global climate change, and actions aimed at its mitigation, will require a transition to fuels and energy technologies that emit less carbon dioxide and other greenhouse gases-substances whose rising concentrations in the atmosphere are thought to be major contributors to global warming and related climatic changes. ${ }^{2}$ Also, the costs associated with the reduction of greenhouse gas emissions will depend on the technologies that become available for deployment in the first decades of the next century. Estimated costs span many orders of magnitude, with even best case scenarios showing costs that range from zero, assuming widely available advanced technologies, to $3 \%$ of gross world product using 1990 vintage technologies. ${ }^{3}$ The challenge is made greater still by virtue of the fact that global energy use is expected to grow by $75 \%$ by 2020 and that most of the new demand will be met with fossil fuels.

In December 1997, official delegations from over 150 countries met in Kyoto, Japan, and signed an international treaty aimed at reducing global emissions of carbon dioxide. Under the Kyoto Protocol, the major industrialized countries agreed to reduce their carbon emissions by 6-8\% from their 1990 levels within the period 2008-2012. Yet the Kyoto Protocol has not been ratified

\footnotetext{
${ }^{1}$ JJ Dooley, "Unintended Consequences: Energy R\&D in a Deregulated Market," Energy Policy (June 1998).

${ }^{2}$ See Intergovernmental Panel on Climate Change, IPCC Second Assessment: Climate Change 1995, p. 13.

${ }^{3}$ Jae Edmonds, James Dooley, and Marshall Wise, "Atmospheric Stabilization: The Role of Energy Technology," in Climate Change Policy, Risk Prioritization, and US Economic Growth (Washington, DC: American Council for Capital Formation, June 1997).
} 
by any major signatories and its prospects, in the United States especially, are dim. There are indications that, while governments of industrialized countries now view the climate change issue with increasing seriousness, there is still insufficient urgency surrounding the problem to precipitate major political action and new government commitments to energy R\&D.

\section{Is the World Prepared for the Emerging Energy Future?}

Considering current trends in energy R\&D and emerging energy challenges, how technologically well-prepared is the world to cope? This study was prompted by the identification of a gap between likely future technology needs and the R\&D investments in the present necessary to meet those needs. Over the period 1985-1995 the nine large OECD countries that support 95\% of the public sector R\&D in the industrialized world, reduced their budgets for energy R\&D by more than $20 \%$ in real terms, on average. Some countries, such as Germany, Italy, and the United Kingdom, cut their budgets by $70 \%$ or more over this decade. ${ }^{4}$

Even more important, below the first-order similarities in industrialized countries' declining energy $R \& D$ expenditures lies a great diversity in the programmatic foci of national energy $R \& D$ investment portfolios. While overall funding levels are certainly important, the composition of countries' R\&D portfolios may be at least as significant as determinants of future technology options. This study seeks to identify and explain some of these critical second-order differences across countries.

\section{Case Selection and Data Used in This Study}

This report presents research findings from case studies of four countries (the United States, Japan, Germany, and the Netherlands) and the European Union. ${ }^{5}$ These countries were selected as the initial cases for this study on the basis of their historic roles as sponsors/performers of energy R\&D, and in consideration of the composition of their current energy R\&D portfolios. This sample set represents the broader population of OECD sponsors of energy R\&D. As some of the world's most important sponsors of energy R\&D, they also illustrate the broad diversity of energy $R \& D$ funding strategies among leading industrialized countries. ${ }^{6}$

This analysis was prepared using data obtained directly from country sources and avoiding data from third party sources such as the Paris-based International Energy Agency (IEA). The use of official country source data facilitated more accurate and more detailed analysis of energy R\&D trends. The use of country source data also enabled the conversion of all currencies into constant 1995 purchasing power parity (PPP) US dollars. In contrast, most third part data sets are

\footnotetext{
${ }^{4}$ International Energy Agency, IEA Energy Technology R\&D Statistics: 1974-1995 (Paris: International Energy Agency, 1997).

${ }^{5}$ For the purpose of this study, the European Union is treated as a single unit or "country," since it is a major sponsor of R\&D and has its own research programs. Although the funding for research is provided by each of the EU's fifteen Member States, the programs are administered at the Community level by officials of the European Commission in Brussels.

${ }^{6}$ In the second phase of this project, the energy R\&D programs of Canada, France, Italy, Switzerland, and the United Kingdom will be surveyed.
} 
converted to US dollars using market exchange rates (MERs). These currency conversion methods can produce dramatically different results from one another.

As the US National Science Board notes in Science and Engineering Indicators 1998, purchasing power parities (PPPs) are preferable to market exchange rates (MER) for converting international R\&D financial data into a common currency. ${ }^{7}$ At their best, MERs represent the relative value of currencies for goods and services traded across borders, measuring a currency's relative buying power at a given point in time. PPPs take into account the cost differences across countries of buying a similar basket of goods and services in numerous expenditure categories including nontradables. PPPs are particularly well suited to measuring the value of goods and services that are not internationally traded; thus, they are well suited to converting R\&D financial data since the vast majority of all nation's R\&D investments are for research carried out within the sponsoring countries' borders. PPPs also tend to be much more stable over time and therefore do not introduce the often large day-to-day and year-to-year fluctuations in MERs, which reduce their statistical usefulness for the purpose of comparing R\&D expenditures.

As Figure 1 shows, changes in dollar-denominated R\&D expenditures converted with market exchange rates can significantly overestimate the true value of the expenditures. The use of MERs can also introduce wild fluctuations into the data being analyzed that are not present in the original local currency denominated figures. For these and many other reasons, MERs are inappropriate for showing trends in these data and will not be used in this research. PPP calculations result in estimates of R\&D expenditures that are considerably closer to countries' actual spending patterns. For example, using purchasing power parities, Japan's public energy R\&D expenditures in 1995 are estimated at approximately $\$ 2.5$ billion; using market exchange rates, however, the total effort will be inaccurately inflated to over $\$ 4.5$ billion (as reported by the IEA). ${ }^{8}$ Consequently, the use of MERs would lead to the incorrect assumption that Japanese public energy R\&D expenditure is more than twice that of the U.S. government's energy R\&D budget (approximately $\$ 2.2$ billion), whereas the use of PPPs show both countries' investments to be of roughly equal size.

\footnotetext{
${ }^{7}$ National Science Board, Science and Engineering Indicators: 1998 (Washington, DC: U.S. Government Printing Office, 1998), p. 4-36.

${ }^{8}$ See International Energy Agency, IEA Energy technology R\&D Statistics: 1974-1995 (Paris: International Energy Agency 1997).
} 
PNNL-12061

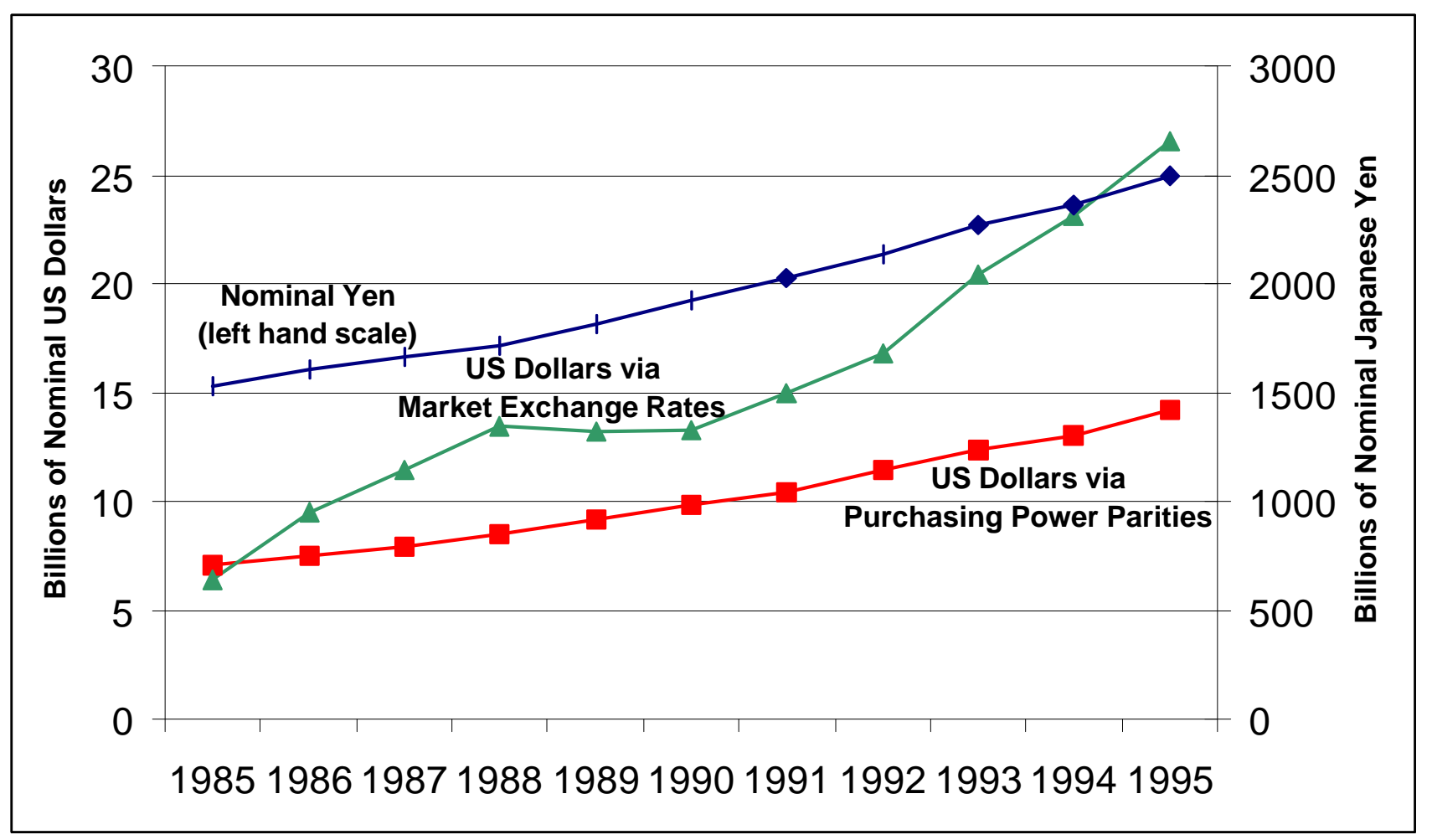

Figure 1: Japanese Public Sector Support for R\&D: 1985-19959

\section{Setting Energy R\&D in Context}

Since the late 1980s, there has been robust and uniform growth in national (public and private sector) investments in R\&D in each of the five cases included here: the United States, Japan, Germany, the European Union, and the Netherlands. In fact, in 1997, overall US investments in R\&D exceeded the $\$ 200$ billion mark for the first time in history. The United States' investments in R\&D grew by 26\% in real terms between 1985 and 1997. Even Japan, which has suffered a prolonged economic recession for most of the 1990s, has expanded its national R\&D effort by 44\% in real terms over the decade 1985-1995. From 1985 to 1995, R\&D in the Netherlands also grew, by $31 \%$ in real terms.

Below this first-order trend of R\&D growth in industrialized countries lies a more diverse array of international trends with regard to funding sources and direction. An important development is the increasingly smaller role played by the public sector as an R\&D sponsor in several countries. In the United States, Germany, and the Netherlands, public sector investments in $R \& D$, as a percentage of the national total, peaked in the late 1980s or early 1990s and have declined in real terms since then or have been roughly stable. In all countries, budget pressure is an important driver for reducing R\&D financing. In the United States and in Germany these

\footnotetext{
${ }^{9}$ Source for budget data: Outline of JFY 1999 Government Budget Requested for Science and Technology. Report Memorandum \#98-14. September 14, 1998. National Science Foundation Tokyo Regional Office. Source for currency conversion rates: NSB Science and Engineering Indicators: 1998, Appendix Table 4-2.
} 
reductions in public support for $\mathrm{R} \& \mathrm{D}$ can be attributed in large measure to the end of the Cold War and the subsequent reordering of social priorities. In the US, major reductions in defense R\&D have been responsible for the overall decline in United States government's R\&D investments. ${ }^{10}$ In Germany, costs associated with the reunification of the country have forced the government to shift funds away from R\&D and toward other national priorities such as addressing unemployment and rebuilding basic infrastructure in the eastern states.

Japan stands out among the cases discussed here, because, in contrast to other industrialized countries, its public sector R\&D investments have increased while private sector investments decreased for most of the past decade. ${ }^{11}$ This is largely the inverse of the other four countries, where robust economic growth has spurred growth in private sector R\&D that has more than offset declining public sector R\&D budgets. In Japan, however, where economic recession has persisted throughout the 1990s, the government has reacted to industry's decreased ability to support R\&D and to the general economic malaise by passing a number of stimulus spending bills, many of which have contained significant sums for R\&D.

In recent years, an important shift has occurred in the focus of public policy relating to $R \& D$. The role of government-funded research in these nations is being rethought. For example, in Germany and the EU, the commercialization of publicly supported R\&D results has become an increasingly important and explicit policy objective, one that might have the effect of displacing investments in more basic research projects. Moreover, there is growing support for the assertion that an increasing short-term focus and market orientation characterize both public and private sector R\&D investments in many industrialized nations.

That said, the United States and Japanese governments have issued policy statements advocating basic science rather than applied research as a primary focus for their public R\&D investments. A widely held belief in the U.S. Congress supports the view that the federal government should limit its R\&D activities to the basic science arena, leaving technology development and commercialization to the private sector. ${ }^{12}$ In Japan, the government has explicitly rejected its former successful policy of adopting and improving on research carried out elsewhere. The Japanese government now believes that it must increase its support for basic research, reducing its dependence on the basic science of other nations. The Dutch government, which is also placing greater emphasis on support for the highest quality basic research, is adopting a selective approach, concentrating its efforts in a smaller array of research areas.

Also, in the three largest R\&D performing countries, the United States, Japan, and Germany, concerted efforts are underway to double (in nominal terms) government investments in civilian R\&D. For its part, Japan is likely to reach its goal of doubling government R\&D investments

\footnotetext{
${ }^{10}$ Reductions in defense R\&D have also had a strong negative impact on the national R\&D efforts of the United Kingdom and France, two countries that will be surveyed in the second phase of this project. (Source NSB Science and Engineering Indicators: 1998).

${ }^{11}$ Recent data suggest that private sector energy R\&D investments in Japan have begun to grow strongly again, beginning in 1997.

12 Vernon Ehlers, "Unlocking Our Future: Toward a New National Science Policy," A Report to Congress by the House Committee on Science, September 24, 1998.
} 
from 1992 levels within a few years of its stated target date of fiscal year 2000. In early November 1998, Germany's new government announced its intention of doubling the public research budget over the next five years. These efforts reflect deep concern on the part of some government officials in each of these countries that the overall health of the national $R \& D$ enterprise not be bound to fluctuations in the business cycle.

\section{Energy R\&D: Decline and Shifting Priorities}

Overall public sector investment levels in energy R\&D have declined over the past decade as the following data show:

- The US federal energy R\&D program has fallen by $26 \%$ over the period $1990-1997$, a decline of more than $\$ 1.2$ billion in real terms from the level in 1990.

- The Japanese government's energy R\&D program declined 8.6\% over the past three years (1996-1998), a real decrease of $\$ 226$ million. As a percentage of total public sector R\&D effort, energy R\&D has fallen from $19.9 \%$ in 1990 to $13.7 \%$ in 1998.

- The German energy R\&D program has declined by $71 \%$ since 1990 , a funding reduction of $\$ 1.04$ billion.

- EU-sponsored energy R\&D has declined by 13\% since 1984; as a fraction of the EU Framework Programme budget, energy R\&D's share has declined from $47 \%$ to $18 \%$ over the same period.

- The Netherlands' public energy R\&D support declined by $28 \%$ in real terms from 1985 to 1995. Support for energy R\&D has recovered somewhat between 1996-1997.

The trends in overall public budgets for energy R\&D tell an incomplete story, however. Figure 2 graphically shows the energy R\&D portfolios of these nations broken out by program area. ${ }^{13}$ Also noteworthy is the fact that national governments have sharply different priorities with regard to energy R\&D technology investment areas. For example Japan devotes $66 \%$ of all public sector energy R\&D expenditures to nuclear fission programs, while the United States and the Netherlands devote a continually declining share-currently less than 8\%--of their energy R\&D resources to fission. ${ }^{14}$ Furthermore, although all of these nations have energy policies that place a very high priority on developing and deploying renewable energy and energy efficient technologies as a way of increasing their energy security and protecting the environment, only the Dutch government invests the majority of its energy R\&D resources in these technology areas.

\footnotetext{
${ }^{13}$ The residual "Other" category on this chart deserves explanation. For the US, this category amounts to nearly half of the US total energy R\&D effort and constitutes the "basic energy sciences" research programs supported by the US Department of Energy. These programs explore fundamental aspects of the science that underpin energy technologies. In the other countries this "Other Energy R\&D" category accounts for programs focusing on systems and policy analysis, as well as some basic research, electric power transmission, distribution, and storage R\&D programs.

${ }^{14}$ At this point in this research effort, these comparisons are rough estimates. This research project is still collecting and standardizing the data from country sources. For example, the US "fission energy R\&D" program might not include US funds for research covered in the other nation's fission R\&D programs such as those used for the geologic disposition of radioactive waste.
} 
PNNL-12061

Interim Report

\section{Figure 2: Public Sector Energy R\&D Portfolios}
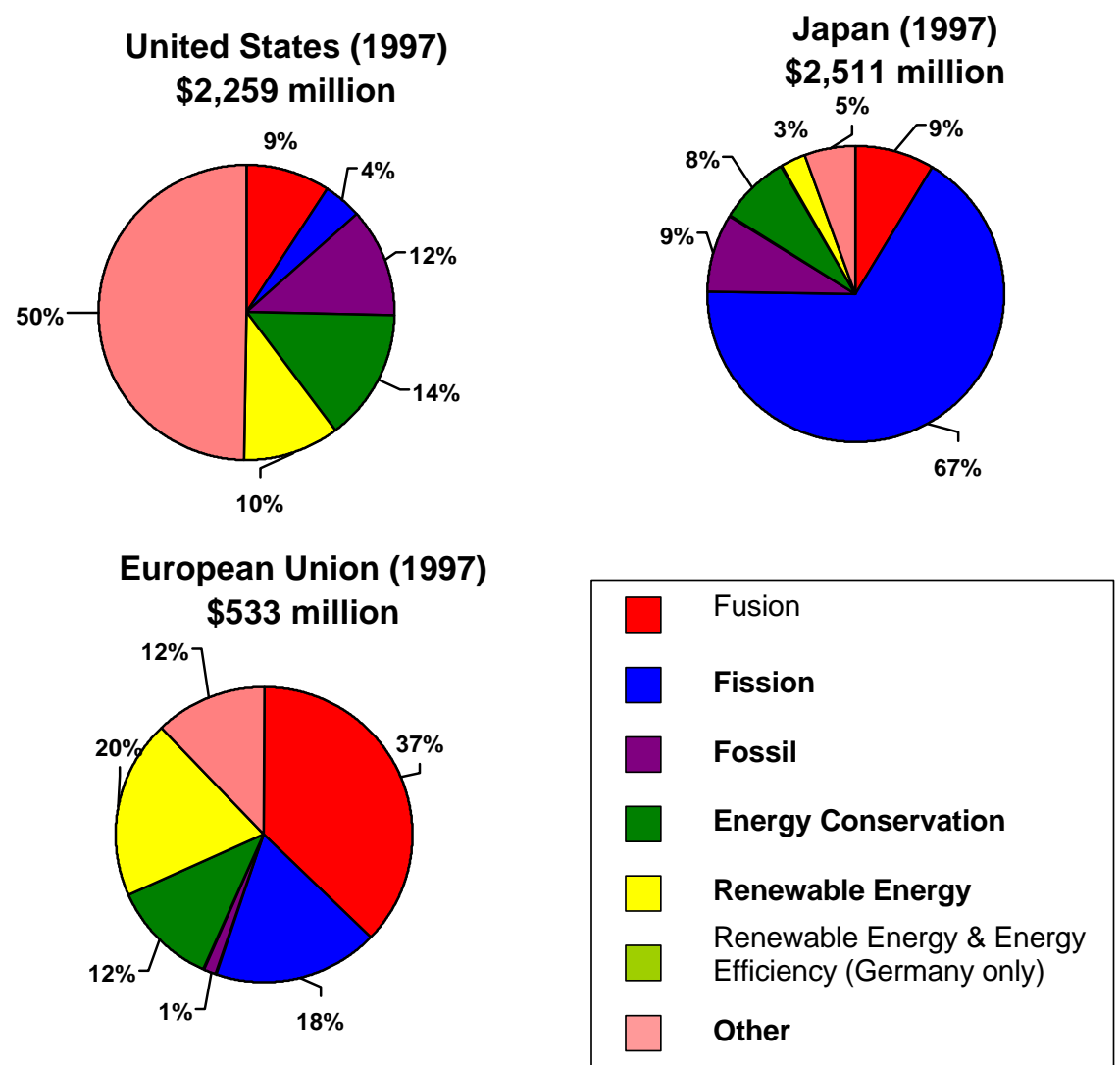

\section{Germany (1996)} $\$ 431$ million

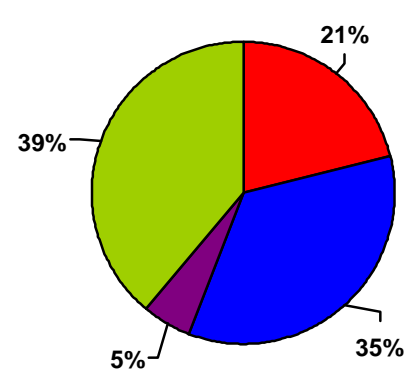

The Netherlands (1997) $\$ 137$ million

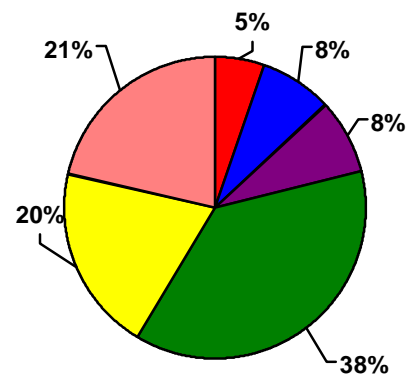

An important observation that arises from this side-by-side analysis of public energy R\&D expenditures is the large variance in the scale of government programs, from the United States' and Japan's expenditures of more than \$2 billion each, to the Netherlands' $\$ 137$ million expenditure. In fact, Japan's fission energy R\&D budget alone is larger than the sum of the Netherlands, EU, and German total energy R\&D budgets. 


\section{Program-Level Trends in Energy R\&D}

This section reviews cross-country patterns and trends in each of four major energy R\&D program areas: fossil energy, energy efficiency, renewable energy, and nuclear energy.

Fossil Energy $R \& D$-Fossil energy R\&D programs in industrialized countries no longer focus, as they did a decade or more ago, on research to locate and characterize new fossil energy resources and to develop new methods of cheaply extracting these resources. To a large extent, fossil energy R\&D programs are also moving away from the development of "clean coal" technology programs designed to improve the efficiency and cleanliness of fossil fuel combustion. The beginning of a potentially significant transition in fossil energy research programs is now discernible, wherein programs are seeking to develop zero carbon dioxide emitting fossil fuel technologies. Amid this transition, technologies that are receiving increasing emphasis include methods to "decarbonize" fossil fuels, programs to develop fuel cells capable of making use of the resulting hydrogen-rich fuel streams, and methods to sequester carbon dioxide. Another noteworthy trend is the expansion of fossil fuel research efforts to investigate the potential for developing new, plentiful, and relatively clean hydrocarbon resources such as methane hydrates and coal bed methane reservoirs. Although these non-conventional programs are currently small, their emergence signals an expansion of the concept of fossil fuels and an expectation of the continued viability of fossil fuels, even under greenhouse gas constraints, well into the next century. The Netherlands and Japan have for example had longstanding research programs examining the efficacy of new fossil energy technologies such as carbon sequestration. Of the countries surveyed, Japan is the largest supporter of these advanced fossil energy research programs (e.g., carbon sequestration, methane hydrates). ${ }^{15}$

Renewable Energy $R \& D$ - In recent years, the focus of industrialized countries' renewable energy R\&D programs has become more concentrated in the area of solar photovoltaics. Wind energy technology research also receives significant support although it appears that the primary objective of wind energy R\&D programs is on technology deployment and commercialization, rather than on the development of new systems and components that would fundamentally improve the efficiency or economics of wind power systems. Interestingly, Japan continues to fund renewable energy technology programs that no longer receive funding from the other countries such as wave/ocean power and waste-to-energy systems. Also, the Japanese government funds a relatively large amount of geothermal research given the abundance of geothermally active sites in Japan. Perhaps the most significant trend in renewable energy research is the relatively flat budgets of these programs throughout the course of the 1990s, a decade that saw increasing rhetoric from national governments pledging to do their best to reduce carbon dioxide emissions through, in part, the increased use of renewable energy systems.

Energy Efficiency -Funding for energy efficiency programs has experienced the most consistent growth of all technology areas. In the United States, for example, public energy efficiency R\&D has increased by 53\% since 1990. Similarly, while Germany's consolidated energy efficiency and renewable R\&D budget has grown only slightly over the past decade, its percentage of the

\footnotetext{
${ }^{15}$ Monastersky, Richard. "The Ice that Burns: Can methane hydrates fuel the $21^{\text {st }}$ century?" Science News. November 14, 1998
} 
total energy R\&D budget has grown since 1985 from $9 \%$ to $39 \%$. The Netherlands' efficiency programs have also grown steadily, now accounting for some $38 \%$ of the Dutch public energy $R \& D$ budget. Industrial energy efficiency programs appear to be receiving preference for $R \& D$ funds over buildings or transportation-related energy efficiency programs. This preference for industrial energy efficiency $R \& D$ likely reflects both a desire to improve competitiveness and to protect the environment. ${ }^{16}$

Nuclear Energy $R \& D$ - The future of nuclear energy and related technologies is in a period of uncertainty in many countries. Many nations are decidedly shifting an ever-larger share of their fission energy R\&D programs away from the development of new reactors and components to focus on research activities concerned with the nuclear fuel cycle, waste disposal, and reactor decommissioning. In Germany and the United States, for example, the fission research budgets have fallen in real terms by more than $90 \%$ over the past decade. With respect to fusion research, Congress' withdrawal of support for U.S. participation in the International Thermonuclear Experimental Reactor (ITER) project and the change in focus of the domestic program from "fusion energy technology development" to "fusion energy sciences" indicates that the commercial availability of fusion energy is still on the distant horizon.

\section{Are Current Energy R\&D Investments Sufficient?}

The governments of most industrialized countries have set out to tighten energy efficiency standards as a primary means of reducing carbon dioxide emissions. For example, Japan has officially stated that there will need to be lifestyle changes, some of which are likely to be "painful" to Japanese citizens. The Japanese government is setting ambitious industrial energy efficiency targets, for instance by requiring all auto manufacturers to surpass the efficiency of the current industry leader within ten years. On the other hand, in the United States, it has been suggested that major emissions reductions could be achieved at no cost through the aggressive deployment of new energy efficiency technologies and the creation of an international carbon permit trading regime. ${ }^{17}$ While in the Netherlands, the government has estimated that attaining an emission reductions goals such as those of the Kyoto Protocol would require annual increases in energy efficiency of approximately $2 \%$, which could entail investments of $\$ 1-2$ billion per year.

Despite major differences across countries in political culture and choices of policy instruments, countries share an assumption that greater energy efficiency will carry them a significant part of the way toward realizing the major carbon emissions reductions in the future. This policy trend raises questions about the prospects for future government support for new, advanced energy technology programs.

\footnotetext{
${ }^{16}$ See Bundesministerium fur Bildung, Wissenschaft, Forschung, und technologie, 4. Programm Energieforschung und Energietechnologien (Bonn: BMBF, 1997), p. 10; European Commission, EC Research Funding (Luxembourg: Office for Official Publications of the European Communities, 1996), p. 15.

${ }^{17}$ Interlaboratory Working Group. 1997. Scenarios of U.S. Carbon Reductions: Potential Impacts of Energy Efficient and Low-Carbon Technologies by 2010 and Beyond (Berkeley, CA: Lawrence Berkeley National Laboratory and Oak Ridge, TN: Oak Ridge National Laboratory), LBNL-40533 and ORNL-444, September (URL address: http://www.ornl.gov/ORNL/Energy_Eff/CON444), Executive Summary.
} 
To a larger extent than has occurred in the United States, government and industry in Japan and Europe have come to a shared view of climate change as presenting potential economic opportunities. In the Netherlands, for example, renewable energy technologies are seen as holding great potential as a future export industry. In the estimation of these governments, climate change provides an impetus for the establishment of international standards for "clean energy technologies" and potential opportunities for those who set the standards to dominate energy technology markets. ${ }^{18}$ Although there are American companies that have adopted similar views, the highly polarized political environment in the United States with regard to climate change has thus far prevented the government and industry from consolidating its position to the extent that European countries and Japan have.

Government funding for renewable energy research is increasingly aimed at helping industry to reduce the costs of energy production using renewable technologies, thereby helping to improve the commercial viability of these technologies. Public funding in this area is aimed principally at improving existing technologies and facilitating their introduction to the market rather than developing new renewable energy technologies. Although the costs of energy from renewable sources has declined significantly over the past decade, renewables face an ongoing challenge in many countries in an era of energy deregulation. The introduction of competition in the electricity industry is reducing the costs of conventionally-generated electricity, effectively neutralizing many of renewable energy sources' recent economic gains and thereby making it more difficult for renewables to expand its share of the electricity generation market.

There is also mounting evidence that the ongoing deregulation of the energy industries in many countries is exerting downward pressure on energy R\&D activities, particularly in the private sector (see Dooley, 1998). While deregulation often leads to positive outcomes such as lower energy prices and more choice for consumers, the competitive dynamics it introduces also heightens managers' and shareholders' sensitivity to short-term market performance indicators. The pressures on private sector energy firms to reduce costs increasingly compel them to reduce their levels of R\&D expenditure and to focus their remaining R\&D investments on shorter-term, product-oriented projects.

By "privatizing" the governance of the energy industries through deregulation, governments redefine the roles of the public and private sectors in providing energy services to the public. Although privatization may bring higher levels of economic efficiency in the energy industries, those gains may compromise the ability to take a long view with regard to the energy future and to invest accordingly in energy $R \& D$.

\footnotetext{
${ }^{18}$ Jacob Park and Paul Runci. "Energy After Kyoto: Opportunities and Challenges for the United States, Japan, and Germany," Workshop Report. Workshop sponsored by the University of Maryland's Harrison Program on the Future Global Agenda and the Mitsubishi International Corporation. College Park, MD. January 30, 1998.
} 


\section{Summary and Next Steps}

This report represents a snapshot of progress made in the initial phase over the course of a few months. The data contained in this report and the conclusions drawn from this report should be viewed as provisional and subject to future revision in response to additional data and comments from peer reviewers. Moreover, as we move to develop the next set of case studies for Canada, France, Italy, Switzerland and the United Kingdom, we will be in a position to better judge the true magnitude and significance of the changes in the industrialized nations' support for energy R\&D.

One particularly interesting question we will address in the next phase of this project is the extent to which these smaller energy R\&D performing nations are now starting to specialize in the development of particular energy technologies. For example, we will seek to assess the extent to which key countries might be moving away from their previous strategy of support for a broad energy R\&D portfolio that would be capable of addressing a wide range of future contingencies, and toward R\&D portfolios that are more specialized and oriented toward a smaller range of energy technologies. It is likely, for example, that problems of public perception and economics might make fission energy R\&D susceptible to deep budget cuts, as has already occurred in the United States and Germany. The development of such trends merits further investigation and analysis.

In addition to carrying out an analysis of some of the energy R\&D programs of these other nations, we intend to make use of economic models such as the Edmonds' MiniCAM and Second Generation Models (see Edmonds, et al., 1997) to assess these national and the aggregate OECD energy R\&D portfolios vis a vis the particular energy policy goal of climate change. For example, Dooley, Edmonds, and Wise (1998) have shown that the continued development of carbon capture and disposal technologies could reduce the cost of stabilizing atmospheric concentrations of carbon dioxide by more than 35\%. The potential cost savings associated with the further development and deployment of these technologies could be on the order of hundreds of billions of dollars.

As we conclude the first phase of this project, we are concerned with an energy technology gap that appears likely to emerge in the midterm. Carbon dioxide disposal, methane hydrates, and nuclear fusion are long-term energy technology prospects likely to become commercially available in the latter half of the next century, while the deployment of today's "advanced" energy efficiency technologies will help achieve some of the more immediate energy policy goals of the present. A key, and still open, questions remains that of the sufficiency of current funding flows for the development of technologies needed in the intervening period to stabilize carbon dioxide levels in the Earth's atmosphere. We will continue to pursue answers to this question and to assess the adequacy of current R\&D efforts in the second phase of this research project. 


\section{Selected Bibliography}

\section{European Union}

Community Research and Development Information Service (CORDIS), http://www.cordis.lu/en/src/i_010_en.htm.

Europa, Internet Server of the European Union, http://www.europa.eu.int.

European Commission, Directorate-General XVII (Energy), "Trans-European Energy Networks: Policy and Actions of the European Community," September 1997.

European Commission, Communication from the Commission: An Overall View of Energy Policy and Actions, 21 April 1997.

European Commission, Directorate-General XII (Science, Research, and Technology), EC Research Funding: A Guide for Applicants, Luxembourg: Office for Official Publications of the European Communities, 1996.

European Commission, White Paper, “An Energy Policy for the European Union,” COM(95)682.

European Commission, Directorate-General XII (Science, Research, and Technology), The Fourth Framework Programme (1994-1998), Luxembourg: Office for Official Publications of the European Communities 1994.

European Commission, The European Report on Science and Technology Indicators 1994 EUR 15897 EN, Luxembourg: Office for Official Publications of the European Communities 1994.

Klom, A.M., "Electricity Deregulation in the European Union," Energy In Europe No. 27, http://europa.eu.int/en/comm/dg17/27klom.htm

Rexrodt, Gunther, "Energy Policy in the European Union," Energy in Europe No. 24.

\section{Germany}

Bundesministerium fur Bildung, Wissenschaft, Forschung, und Technologie. Basic and Structural Data 1996/97. Berlin: BMBF, 1996.

Bundesministerium fur Bildung, Wissenschaft, Forschung, und Technologie. Bundesbericht Forschung 1996. Berlin: BMBF, 1996.

Bundesministerium fur Bildung, Wissenschaft, Forschung, und Technologie. 4. Programm Energieforschung und Energietechnologien. Berlin: BMBF, 1997. 
Bundesministerium fur Wirtschaft. Energie Daten '97/’98. Berlin: Bundesministerium fur Wirtschaft, 1998.

Bundesministerium fur Wirtschaft. "Klimaschutz und Energiepolitik: 4. Bericht des Arbeitskreises I, 'Energieversorgung der Interministeriellen Arbeitsgruppe CO2-Reduktion,' Dokumentation Nr. 445," Berlin: Bundesministerium fur Wirtschaft, 1998.

Markewitz, Peter, and Dag Martinsen. "Reduction of Energy Related Emissions of Greenhouse Gases in Germany." Juelich: Research Center Juelich, 1997.

Peter, Matthias. "FEuD in der Elektrizitatswirtschaft 1995-Ergebnisse der VDEW-Umfrage fur den nicht-nuklearen Bereich,” Elektrizitatswirtschaft, Jg. 96 (1997), Heft 12.

\section{$\underline{\text { Japan }}$}

Agency for Industrial Science and Technology. "Agency for Industrial Science and Technology 1997-1998." Tokyo, 1998

Agency for Industrial Science and Technology. "Trends in Principal Indicators on Research and Development Activities in Japan: 1997.” Tokyo: 1997.

Alexandar, Arthur. "Basic Research and Science in the Japanese Economy" Report No. 11A. Washington, DC: Japan Economic Institute, March 1997.

Choy, Jon. "Research and Development in Japan: Squeezing More from Every Yen" Report No. 29A. Washington, DC: Japan Economic Institute, July 1998.

Ministry of International Trade and Industry. Statistics on Japanese Industries: 1998. Tokyo, 1998.

Ministry of International Trade and Industry/ANRE. Energy in Japan: Facts and Figures. Tokyo, 1998.

Ministry of International Trade and Industry Japan/Agency of Industrial Science and Technology. New Sunshine Program: R\&D Program on Energy and Environmental Technologies

National Institute for Resources and Environment (NIRE). "Technologies to Minimize Environmental Burden and Maximize Resource Utilization, Part I: New Energy."

U.S. National Science Foundation, Tokyo Regional Office. "1997 Survey Of Research And Development In Japan,” Report Memorandum \#97-13 (December 3, 1997). NSF translation of "summary report" of the Japanese Statistics Bureau, Management and Coordination Agency, November 27, 1997. 
PNNL-12061

Interim Report

\section{The Netherlands}

Centraal Bureau voor de Statistiek (CBS) (September 1997), Kennis en Economie 1997 (Knowledge and Economy 1997), Voorburg/Heerlen, Netherlands Central Bureau of Statistics, The Netherlands.

Centraal Bureau voor de Statistiek (CBS) (1996), De Nederlandse Energiehuishouding: Jaarcijfers 1996 (Energy Supply in the Netherlands: Annual Figures), Voorburg, The Netherlands.

Ministry of Economic Affairs (1995), Derde Energienota (Third White Paper on Energy), The Hague, The Netherlands.

Ministry of Economic Affairs (March 1997), Duurzame Energie in Opmars - Actie programma 1997-2001 (Action Plan for Renewable Energy - 1997-2001), The Hague, The Netherlands.

Ministry of Economic Affairs (April 1998a), Energiebeparingsnota (Memorandum on Energy Conservation), The Hague, The Netherlands.

Ministry of Economic Affairs (April 1998b), Energie Onderzoek in Nederland - Organisatie en Prioriteiten, (Energy Research in the Netherlands - Organisation and Priorities), The Hague, The Netherlands.

Ministry of Education, Culture and Sciences, (yearly report), Wetenschapsbudget (Science Budget), Zoetermeer, The Netherlands.

Novem B.V. (yearly report), Annual Report, Utrecht, The Netherlands.

Struker, A. and D. de Jager (April 1998), Survey of Publicly Financed Energy Research in The Netherlands - 1995, 1996, 1997 (estimates), Ecofys Consultancy, Utrecht, The Netherlands.

Tijssen, R.J.W., Th. N. van Leeuwen, et al. (1998), Wetenschaps - en Technologie- Indicatoren 1998 (Science and Technology Indicators 1998), Leiden / Maastricht, Centrum voor Wetenschaps- en Technologie Studies (CWTS), Rijksuniversiteit Leiden / Maastricht Economic Research Institute on Innovation and Technology (MERIT), Universiteit Maastricht, The Netherlands.

\section{$\underline{\text { United States }}$}

Central Intelligence Agency. World Factbook, 1997.

Council of Economic Advisors. The Kyoto Protocol and the President's Policies to Address Climate Change: Administration Economic Analysis. Washington, DC, 1998. 
PNNL-12061

Dooley, JJ. "Unintended Consequences: Energy R\&D in Deregulated Market." Energy Policy. pp. 547-555. June 1998.

Edmonds, JA, JJ Dooley, MA Wise. "Atmospheric Stabilization: The Role of Energy Technology" published in Climate Change Policy, Risk Prioritization, and US Economic Growth. Proceedings of a conference sponsored by the American Council for Capital Formation Center for Policy Research held in Washington, D.C., September, 1996. American Council for Capital Formation, Washington, D.C. June 1997.

Ehlers, Vernon. "Unlocking Our Future: Toward a New National Science Policy," A Report to Congress by the House Committee on Science, September 24, 1998.

Interlaboratory Working Group. 1997. Scenarios of U.S. Carbon Reductions: Potential Impacts of Energy -Efficient and Low-Carbon Technologies by 2010 and Beyond. Berkeley, CA:

Lawrence Berkeley National Laboratory and Oak Ridge, TN: Oak Ridge National Laboratory, LBNL-40533 and ORNL-444. http://www.ornl.gov/ORNL/Energy Eff/CON444

National Science Board. Science and Engineering Indicators-1998 (NSB 98-1). Washington, DC: U.S. Government Printing Office, 1998.

President's Committee of Advisors on Science and Technology. Federal Energy Research and Development Challenges of the Twenty-First Century. Washington, DC: The White House, 1997.

U.S. Department of Energy/Energy Information Agency. "United States of America: Country Analysis Brief." 